\title{
A structural performance evaluation of vertical housing model due to the increased seismic loads in Semarang, Indonesia using a pushover analysis
}

\author{
Arnie Widyaningrum ${ }^{1, *}$ Yanuar Haryanto ${ }^{1}$, and Nor Intang Setyo Hermanto ${ }^{1}$ \\ ${ }^{1}$ Jenderal Soedirman University, Civil Engineering Department, Jl. Mayjend.Sungkono KM 5, Blater, \\ Purbalingga, 53371, Indonesia
}

\begin{abstract}
The substantial increase in design response spectrum is resulted from the Indonesian seismic regulation changes, which occur in Semarang as well, either for hard, medium or soft site class. The increased design response spectrum is linear to the increased seismic loads, which may influence the structural performance of buildings in Semarang. We have conducted a study on the influence of increased seismic loads on the performance of an irregular ten-story vertical housing model of medium site class in Semarang, Indonesia. The study is conducted using a pushover analysis. We find that the increased seismic loads in Semarang has resulted in the increased base shear force and structural drift of the analysed vertical housing model. The base shear force increases by $68.96 \%$ in $\mathrm{X}$ direction and $66.63 \%$ in $\mathrm{Y}$ direction, while the structural drift ratio increases by $81.25 \%$ in $\mathrm{X}$ direction and $82.64 \%$ in $\mathrm{Y}$ direction. However, the structural performance remains at Immediate Occupancy, which refers to a condition of post-earthquake damage where the building is still regarded as safe to live in.
\end{abstract}

\section{Introduction}

Earthquakes are unpredictable in terms of time and location. Earthquakes may cause damage to buildings and result in fatalities [1]. Indonesia is one of the places where active plates of the world meet, which make its seismic intensity relatively high. Any change in the seismic intensity requires a change in the regulation of seismic design for building due to the result of increased design response spectrum for all site classes throughout Indonesia. This regulation change has caused researchers to conduct many studies regarding the influence of regulation change on the existing seismic force and its impact on building structural performance. One of the studies was conducted by Arfiadiand Satyarno [2]. This study compared the design spectrum of several big cities in Indonesia according to SNI 03-17262012 [3] and SNI 03-1726-2002 [4] and it was found that the substantial increase in design spectrum occurs in Semarang for all site classes. The increased design response spectrum is

* Corresponding author: arnie.wyd@gmail.com 
linear to the increased seismic load, which may influence the structural performance of buildings in Semarang particularly for buildings which are higher than a 2-story building and for irregular shaped buildings.

Semarang is the capital city of Central Java Province, which is one of the most densely populated cities. To overcome the increasing demand for housing, vertical housing models, commonly known as apartments, are developed. The objective of this study is to evaluate the performance of an irregular 10-story vertical housing structure model in Semarang due to the result of the increased seismic load caused by the Indonesian seismic regulation changes. The building behaviour during the occurrence of earthquakes depends on some factors, including whether its shape is simple and symmetrical. An irregular shaped building, either vertical or horizontal, is more vulnerable to earthquakes [5]. Some buildings even behave badly when an earthquake occurs, which is caused by their irregular shape [6].

Kharwar and Lhonde [7] argue that a hierarchical structural analysis is suitable to performance-based structural analysis. High-level procedure is able to offer a more precise technique for the real performance of a building depending on earthquake loads; however, more effort is needed which involves preparation of data, time and computational efforts. Pushover analysis is a popular technique which is recommended to be used in evaluating the performance of long established and new structures [8] in terms of its simplicity [9]. Pushover analysis can evaluate building loaded beyond its elastic range, especially for higher mode effects. Pushover analysis can yield sufficient data regarding seismic demand with the exploitation of design ground motion on structural system as well as its components. Existing buildings may be classified as seismically insufficient due to the increasing requirements of seismic regulation besides the advancement of engineering science.

\section{Methodology}

\subsection{Structure modeling}

The vertical housing model to be evaluated is a 10-story building which is adjusted to the criteria of horizontal irregularity, in which the dimension of $\mathrm{X}$ and $\mathrm{Y}$ directions is different from the designated medium site class. Simplification is made in this design whereby the stiffness level of positive and negative $\mathrm{X}$ axis directions is evenly matched with the stiffness level of positive and negative $\mathrm{Y}$ axis directions. The taken dead load includes structure weight, consisting of beam, column, wall and floor plate profiles. To insert wall load, distributed load on beam is used, while the plate load is modeled as properties pursuant to the plate dimension. The layout structure can be found in Figure 1. The 2D model of vertical housing to be evaluated can be found in Figure 2 and the 3D model can be found in Figure 3.

The main structure consists of the column of IWF 400.400.16.24 profile for floors 1-5 and IWF 350.350.14.22 profile for floors 6-10; beam element that uses IWF 400.200.8.13 profile with 64 shear connectors which are installed 2 pcs per $18.75 \mathrm{~cm}$ of length for floors 1-9, and IWF 250.250.14.14 profile with 58 shear connectors which are installed 2 pcs per $20.69 \mathrm{~cm}$ of length for roofbeam. Bracing uses IWF 200.200.12.12 profile, and stair design results in calculation of optrede of $20 \mathrm{~cm}$, antrede $25 \mathrm{~cm}$ and angle $38^{\circ}$ with a total of 19 steps. Floor plate uses $12 \mathrm{~cm}$ thick reinforced concrete. 


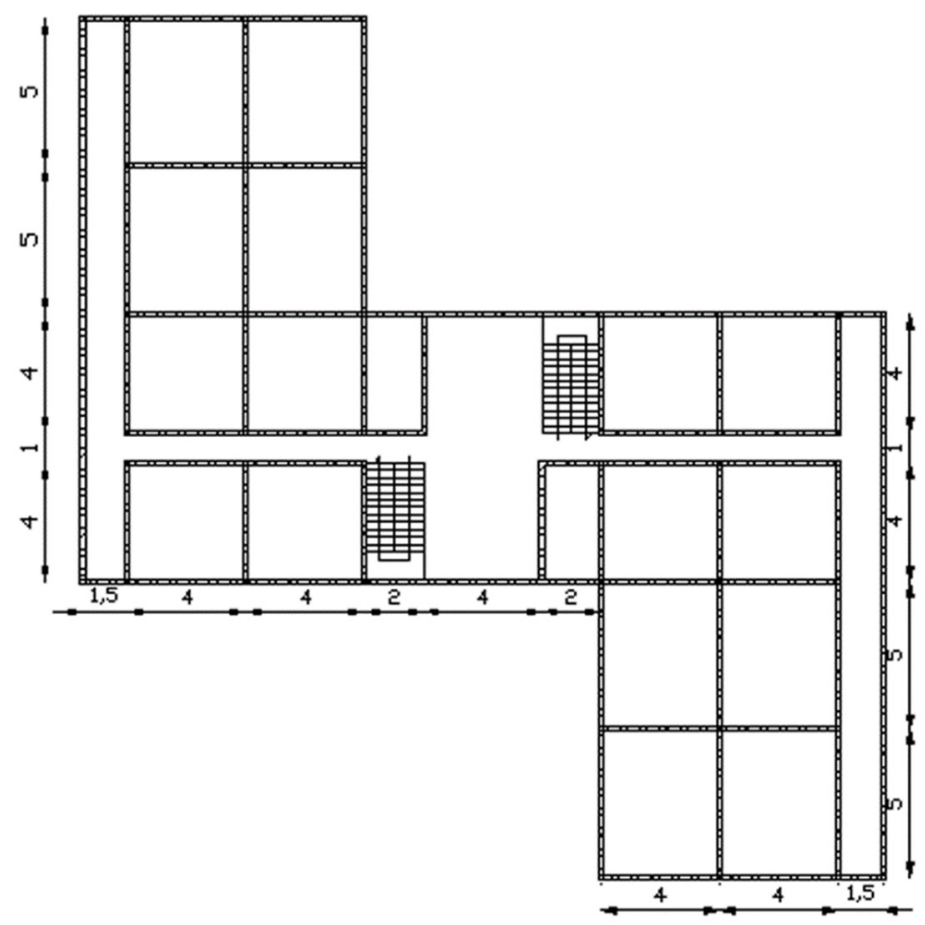

Fig. 1. Structure layout.

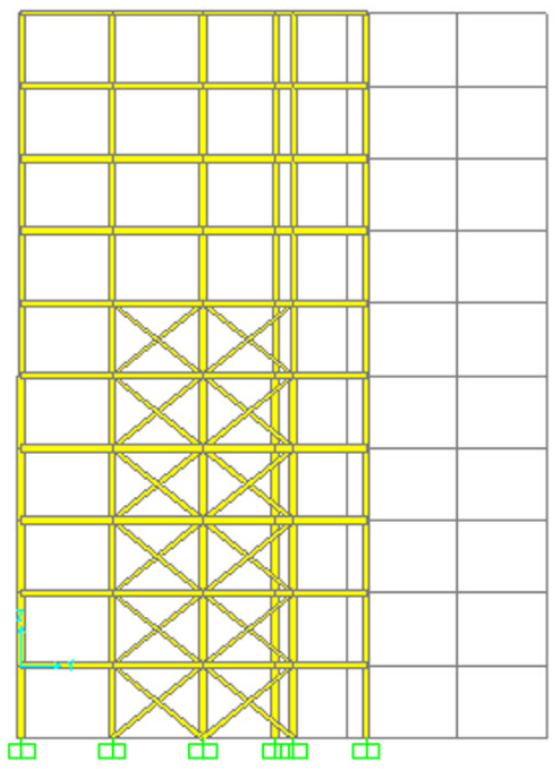

Fig. 2. 2D model of vertical housing to be evaluated. 


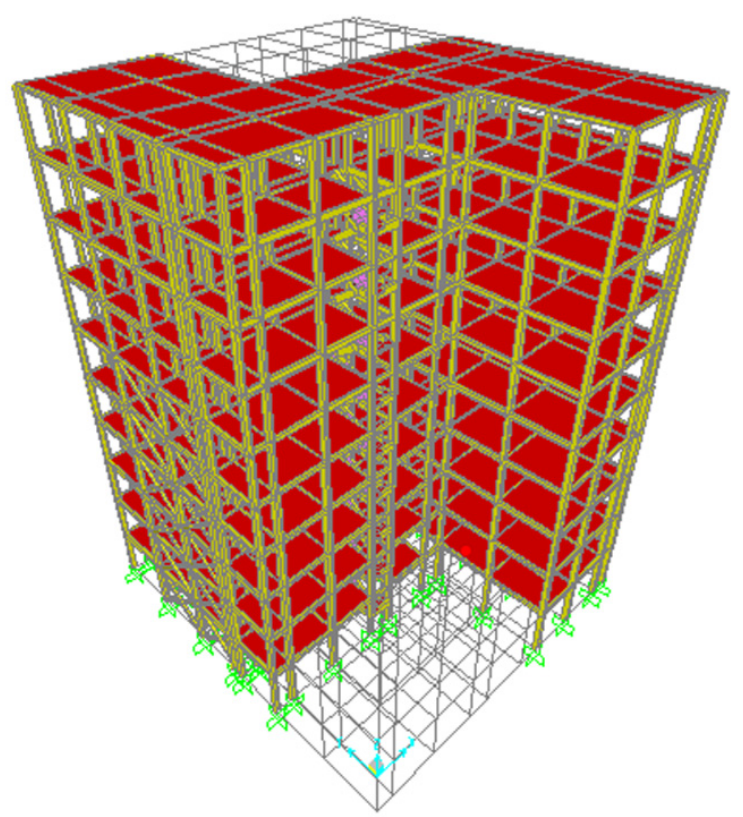

Fig. 3. 3D model of vertical housing to be evaluated.

\subsection{Pushover analysis}

A pushover analysis is carried out by exposing a structure to lateral loads with a monotonically increasing pattern, depicting the inertial forces that the structure may have to sustain while exposed to ground shaking. With the loads being increased gradually, several structural elements can be yielded in succession. As a result, the structure loses its stiffness in every event. The application of pushover analysis can help to ascertain a non-linear force displacement relationship. The generalised force-displacement attribute of a non-degrading frame element (or hinge properties) is illustrated in Figure 4.

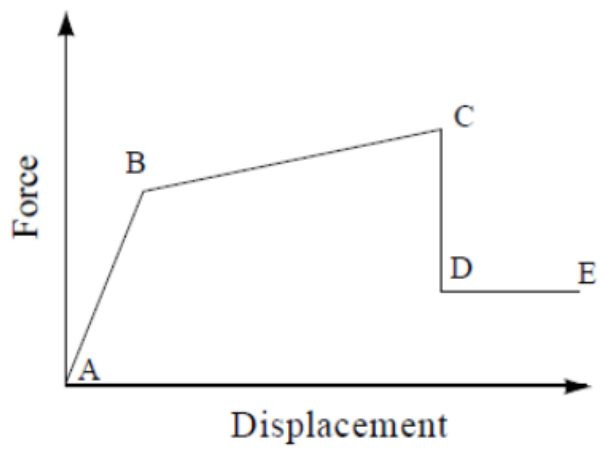

Fig. 4. Generalised force-displacement attribute of frame element.

Point $\mathrm{A}$ is equivalent to the unloaded condition and point $\mathrm{B}$ stands for the yield of the element. The ordinate at point $\mathrm{C}$ is equivalent to nominal strength, while the abscissa at point $\mathrm{C}$ is equivalent to the deformation where strength degradation starts to occur. The decline from point $\mathrm{C}$ to point $\mathrm{D}$ stands for the initial failure of the element and the resistance to lateral 
loads beyond point $\mathrm{C}$ is generally undependable. The residual resistance from point $\mathrm{D}$ to point $\mathrm{E}$ enables gravity loads to be supported by the frame elements. Beyond point $\mathrm{E}$ which stands for the maximum deformation capacity, gravity load may not be supported anymore.

\subsection{Capacity and demand}

The general capacity of a structure relies on the strength and deformation capacities of its individual components. In pushover analysis procedure, a sequence of sequential elastic analysis is applied and superimposed so as to describe the force-displacement capacity diagram of the whole structure. To explain reduced resistance of yielding components, the mathematical model of the structure is adapted. A lateral force distribution is used till a predetermined limit is attained. Pushover capacity curves describe the behaviour of a structure after going beyond the elastic limits.

When an earthquake occurs, ground motions bring forth patterns of complex horizontal displacement in a structure which may fluctuate from time to time. It is certainly unrealistic to keep track of this motion for the purpose of ascertaining the conditions of structural design. For a non-linear approach, a set of lateral displacement is utilised as a design condition for a specified ground motion and structure, given that the displacement is an approximation of the maximum anticipated response of a building when the ground motion exists.

\section{Result and discussion}

As the result of pushover analysis, performance point, which is the point that intersects capacity spectrum with suitable demand spectrum in the capacity spectrum approach [10], is presented in Figure 5. From this pushover analysis result, we can reveal the value of base shear force (V) and the value of displacement (D) that takes place. The values of $\mathrm{Sa}, \mathrm{Sd}$, effective natural vibration time ( $\left.\mathrm{T}_{\text {eff }}\right)$ and effective viscous damping $\left(\beta_{\text {eff }}\right)$ can be determined. With reference to SNI 1726-2002 and SNI 1726: 2012, the results of this study are depicted in Table 1. From Table 1, it was found that the base shear force for $\mathrm{X}$ and $\mathrm{Y}$ directions have increased by $68.96 \%$ and $66.63 \%$ respectively for vertical housing building model in Semarang while the performance point is attained. Structure ductility, which is the ratio of ultimate displacement $\left(\delta_{\mathrm{u}}\right)$ and yield displacement $\left(\delta_{\mathrm{y}}\right)$, is tabulated in Table 2.

Table 1. Pushover analytical results.

\begin{tabular}{|c|c|c|c|c|c|c|c|}
\hline SNI & Direction & $\mathbf{V ~ ( k N )}$ & $\mathbf{D}(\mathbf{m})$ & $\mathbf{S a}$ & $\mathbf{S d}$ & Teff $_{\text {ef }}$ & $\boldsymbol{\beta}_{\text {eff }}$ \\
\hline \multirow{2}{*}{2002} & $\mathrm{X}$ & 7058.659 & 0.160 & 0.137 & 0.096 & 1.677 & 0.050 \\
\cline { 2 - 8 } & $\mathrm{Y}$ & 12339.800 & 0.144 & 0.183 & 0.086 & 1.376 & 0.089 \\
\hline \multirow{2}{*}{2012} & $\mathrm{X}$ & 11926.500 & 0.290 & 0.236 & 0.173 & 1.719 & 0.050 \\
\cline { 2 - 8 } & $\mathrm{Y}$ & 20561.540 & 0.170 & 0.313 & 0.170 & 1.476 & 0.115 \\
\hline
\end{tabular}

Table 2. Structure ductility.

\begin{tabular}{|c|c|c|c|c|}
\hline SNI & Direction & $\boldsymbol{\delta y}(\mathbf{m})$ & $\boldsymbol{\delta} \mathbf{u}(\mathbf{m})$ & $\begin{array}{c}\text { Structure } \\
\text { Ductility }\end{array}$ \\
\hline \multirow{2}{*}{2002} & $\mathrm{X}$ & 0.3584 & 0.6858 & 1.9133 \\
\cline { 2 - 5 } & $\mathrm{Y}$ & 0.0594 & 0.3586 & 6.0384 \\
\hline \multirow{2}{*}{2012} & $\mathrm{X}$ & 0.3828 & 0.7622 & 1.9910 \\
\cline { 2 - 5 } & $\mathrm{Y}$ & 0.0628 & 0.3006 & 4.7892 \\
\hline
\end{tabular}




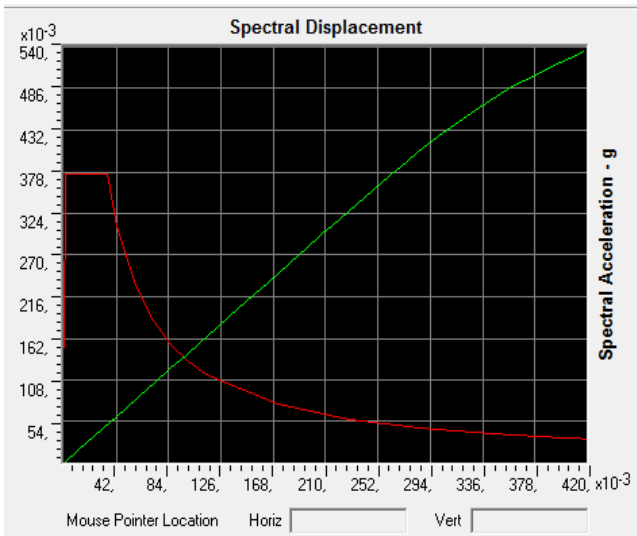

(a) SNI $2002 \mathrm{X}$ direction

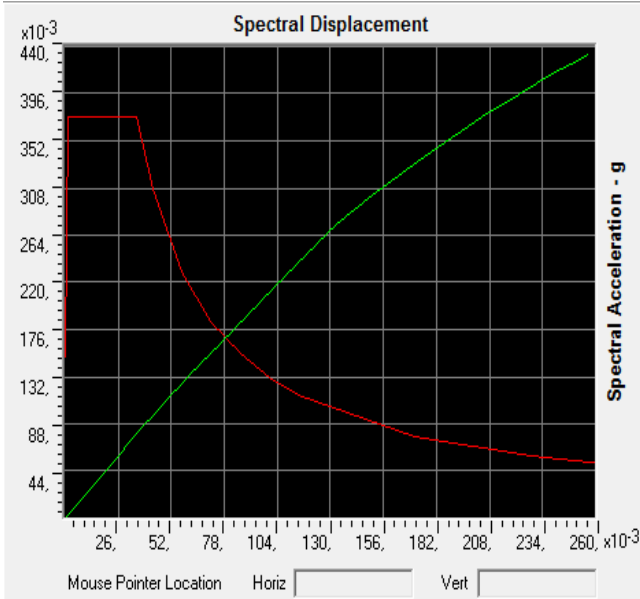

(c) SNI 2002 Y direction

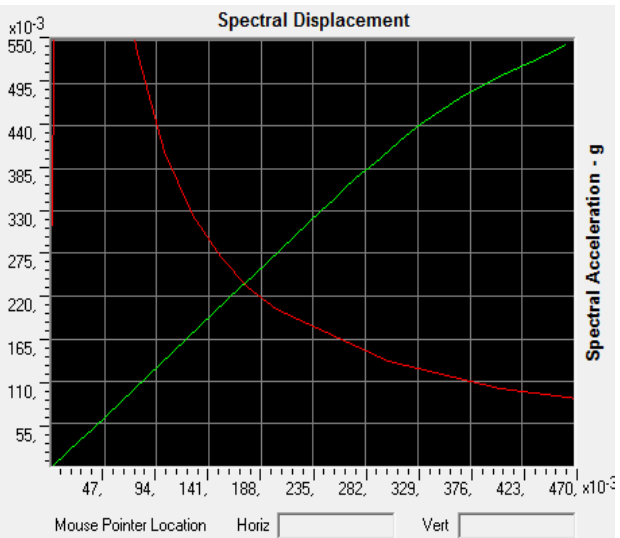

(b) SNI $2002 \mathrm{X}$ direction

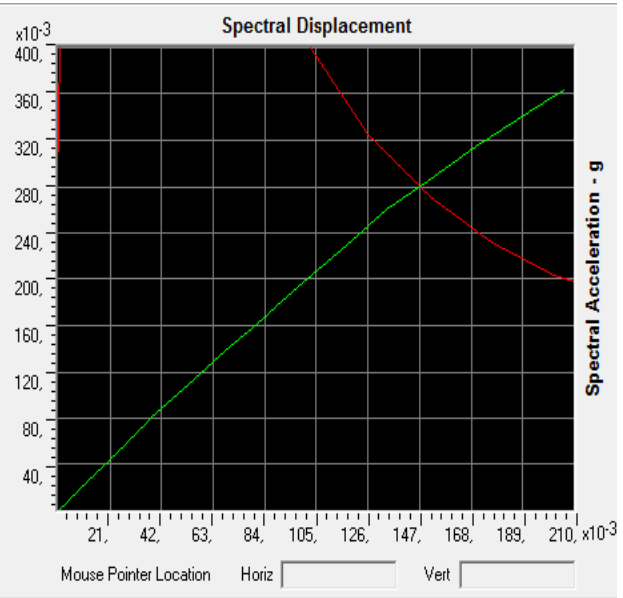

(d) SNI 2012 Y direction

Fig. 5. Performance point.

Under the pushover analysis, the structural performance of vertical housing building model in Semarang is determined according to drift ratio, by comparing the drift of the control point (roof) with its respective height. The results of this analysis reveal that the existing drift ratio for seismic load of SNI $1726-2002$ is $0.40 \%$ and $0.29 \%$ respectively in the $\mathrm{X}$ and $\mathrm{Y}$ directions. Meanwhile, the existing drift ratio for seismic load of SNI 1726-2012 is $0.73 \%$ and $0.66 \%$ respectively in the $\mathrm{X}$ and $\mathrm{Y}$ directions. The story drift of pushover analytical results is shown in Figure 6 and the structural performance is depicted in Table 3.

Table 3. Structural performance.

\begin{tabular}{|c|c|c|c|c|}
\hline \multirow{2}{*}{ Direction } & SNI & Dt(m) & $\begin{array}{c}\text { Drift Ratio } \\
(\mathbf{\%})\end{array}$ & Performance \\
\hline \multirow{2}{*}{$\mathrm{X}$} & 2002 & 0.160 & 0.40 & $I O$ \\
\cline { 2 - 5 } & 2012 & 0.144 & 0.73 & $I O$ \\
\hline \multirow{2}{*}{$\mathrm{Y}$} & 2002 & 0.29 & 0.36 & $I O$ \\
\cline { 2 - 5 } & 2012 & 0.263 & 0.66 & $I O$ \\
\hline
\end{tabular}



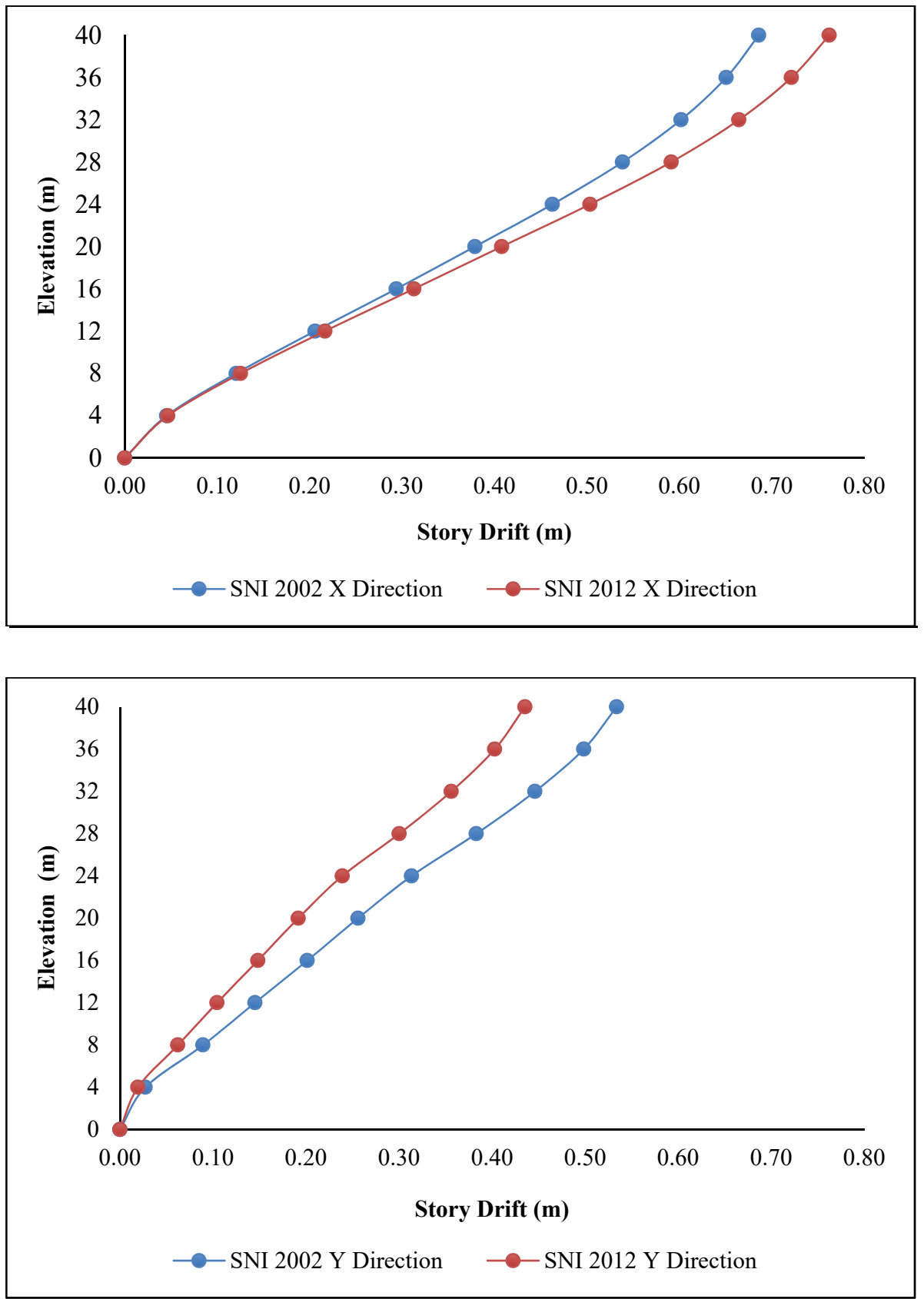

Fig. 6. Story drift.

Figure 6 shows the drift of vertical housing building model in Semarang. From Figure 6, it was found that the story drift in the $\mathrm{X}$ direction is higher than the $\mathrm{Y}$ direction, and this is due to the different stiffness of the bracing installation in the $\mathrm{Y}$ direction. Table 3 shows that the structural drift ratio increases by $81.25 \%$ for the $\mathrm{X}$ direction and $82.64 \%$ for the $\mathrm{Y}$ direction. However, the structural performance remains at Immediate Occupancy, which refers to a condition of post-earthquake damage where the building is still regarded as safe to live in. 


\section{Conclusions}

With reference to the pushover analytical results of the irregular 10-story vertical housing building model in Semarang, it is concluded that the result of the increased seismic load is due to the regulation changes between SNI 1726-2002 to SNI 1726: 2012. The base shear force increases by $68.96 \%$ and $66.63 \%$ respectively for $\mathrm{X}$ and $\mathrm{Y}$ directions, while the drift ratio increases by $81.25 \%$ and $82.64 \%$ respectively for $\mathrm{X}$ and $\mathrm{Y}$ directions. The existing drift ratio for seismic load of SNI $1726-2002$ is $0.40 \%$ and $0.29 \%$ respectively in $\mathrm{X}$ and $\mathrm{Y}$ directions, while the existing drift ratio for seismic load of SNI 1726: 2012 is $0.73 \%$ and $0.66 \%$ respectively in $\mathrm{X}$ and $\mathrm{Y}$ directions. Since the existing drift ratio is less than $1 \%$, the structural performance remains at Immediate Occupancy (IO). The possibility of fatal injuries due to structural damage is very small. Even though it may be suitable to have some minor restorations of structural damage, these may normally not be needed prior to re-occupancy. The plastic hinge distribution reveals that the collapse begins first at the beam elements.

The authors would like to thank LPPM UNSOED which has funded this study as one part of the Competence Enhancement Research. The authors would also like to show their appreciation to Muhammad Reza Septyansyah for providing valuable assistance and contribution in allowing this study to achieve its goals.

\section{References}

1. Y. Haryanto, G.H. Sudibyo, F.C.A. Effendi, Procedia Eng. 171, 1025 (2017)

2. Y. Arifadi, I. Satyarno, Perbandingan Spektra Desain Beberapa Kota Besar di Indonesia dalam SNI Gempa 2012 dan SNI Gempa 2002 (2013)

3. The National Standardization Agency of Indonesia, SNI 03-1726-2002 Tata cara perencanaan ketahanan gempa untuk bangunan gedung (2002)

4. The National Standardization Agency of Indonesia, SNI 1726: 2012 Tata cara perencanaan ketahanan gempa untuk struktur bangunan gedung dan non gedung (2012)

5. Y. Haryanto, B.S. Gan, N.G. Wariyatno, E.W. Indriyari, ARPN JEAS, 12, 4858 (2017)

6. C.V.R. Murty, S. Brzev, H. Faison, C.D. Comartin, A. Irfanoglu, Perilaku Bangunan Struktur Rangka Beton Bertulang dengan Dinding Pengisi Dari Bata Terhadap Gempa (2009)

7. D.B. Karwar, R.S. Londhe, IJETAE, 4, 488 (2014)

8. N. Bodige, P.K. Ramancharla, Pushover Analysis of RC Bare Frame: Performance Comparison between Ductile and Non-ductile detailing (2012)

9. A.Q. Bhatti, H. Varum, Application of Performance Based Nonlinear Seismic Design and Simulation Static Pushover Analysis for Seismic Design of RC Buildings (2012)

10. Applied Technology Council, Seismic evaluation and retrofit of concrete buildings, Vol. 1 (ATC-40) (1996) 